TODA, T., M. TAJIMA, K. NishimURA and H. TAKEUCHI (1993): Resistance breeding to the pine wood nematode in Kyushu district - Progress of study after selection of the resistant clones. Bull For Tree Inst 11: 37-88 (in Japanese with English summary).

VAN DE VEN, W. T. G. and R. J. MCNicOL (1995): The use of RAPD markers for the identification of Sitka spruce (Picea sitchensis) clones. Heredity 75: 126-132.

Wang, C.-W., T. O. Perry and A. G. Johonson (1960): Pollen dispersion of slash pine (Pinus elliotii Engelm.) with special reference to seed orchard management. Silvae Genetica 9: $78-86$.

WheELER, N. C. and K. S. JECH (1992): The use of electrophoretic markers in seed orchard research. New Forests 6: 311-328.

Williams, J. G. K., A. R. KubELIK, K. J. LivAK, J. A. RAFALSKI and S. V. TINGEY (1990): DNA polymorphisms amplified by arbitrary primers are useful as genetic markers. Nucleic Acids Res 18: 6531-6535.

\title{
Seed Source Variation in Morphology, Germination and Seedling Growth of Jatropha curcas Linn. in Central India
}

\author{
By H. S. Ginwal ${ }^{1, *}$, S. S. Phartyal ${ }^{1}$, P. S. RawaT ${ }^{2}$ and R. L. SRIVAstava ${ }^{3}$
}

(Received 10 ${ }^{\text {th }}$ May 2005)

\begin{abstract}
The aim of the study was to determine source variation in Jatropha curcas seeds collected from ten locations in Central India. A significant seed source variation was observed in seed morphology (colour, size and weight), seed germination (viability, germination percent, germination energy, germination value) and seedling growth parameters (survival percentage, seedling height, collar diameter, leave/plant, and seedling biomass). The seed source of Chhindwara (M.P.) was found as the best source in comparison to others. The phenotypic and genotypic variance, their coefficient of variability and broad sense heritability also showed a sizeable variability. This offers a breeder ample scope to undertake screening and selection of seed sources for the desired traits. Further, high percentage of heritability coupled with moderate intensity of genetic gain, was observed for seed germination traits, which signifies that germination is under strong genetic control and good amount of heritable additive genetic component can be exploited for improvement of this species.
\end{abstract}

Key words: Jatropha curcas, variation, seed source, variability, heritability, genetic gain, seed germination, germination energy.

\section{Introduction}

Jatropha curcas Linn. (physic nut or Ratanjot), a genus of family Euphorbiaceae, is believed to be a native of Mexico and Central America. It has been introduced in Africa and Asia and is now cultivated worldwide. Por-

\footnotetext{
1) Division of Genetics and Tree Propagation, Forest Research Institute, PO- I.P.E., Kaulagarh Road, Dehradun-248195, UA, INDIA.

$\left.{ }^{2}\right)$ Research and Coordination Section, Forest Research Institute, PO- New Forest, Dehradun-248006, UA, INDIA.

3) Arid Forest Research Institute, PO-Krishi Mandi, New Pali Road, Jodhpur-342005, Rajashthan, INDIA

*) Authors for corresponding: ginwalhs@rediffmail.com
}

tuguese introduced physic nut as an oil yielding plant in India. It is a multipurpose, deciduous, small tree (or large shrub), reported to be cultivated in drier sites of central and western parts of India. Recently, it has also been introduced in the northern and southern states under massive plantation work to enhance livelihood of rural people and simultaneously to develop wasteland. Jatropha curcas is a prominent species with vide variety of uses. Seeds, leaves and bark are used in traditional medicine and for veterinary purposes. The oil has a strong purgative action and is also widely used for skin diseases and to soothe rheumatic pain. A decoction of leaves is used against cough and as an antiseptic after birth (HELLER, 1996).

In recent years energy conservation and its alternative production has acquired significant importance in the wake of the world energy crisis. Since the oil crisis of the 1970s and recognition of the limitations of world oil resources, most of the oil importing countries including India has been highly motivated to develop alternative sources of energy to meet their domestic needs from natural resources. J. curcas has been found highly promising species which can yield oilseed as a source of energy in the form of bio-diesel owing to its short gestation period, hardy nature, high quality oil content, etc. The oil can also be used in soap and candle industries and its by-product glycerine can be used in the pharmaceutical industry.

Considering vast semi-wild distribution of J. curcas in different parts of India, it would be expected to have considerable genetic variation. Sufficient information on such aspect is lacking in this species in spite of its many uses. Environmental factors in combination with genetic and physiological factors play important role in determination of plant potential for seed quality. These characters appear to be under strong genetic control (Roy et al., 2004). Depending on the species, germination 
responses of seed vary according to geographical and environmental factors, viz. latitude, elevation, soil moisture, soil nutrient, temperature, kind and density of plant cover, degree of habitat disturbance of the site where the seed matures. So far, only few records of provenance trials of the J. curcas exist where an attempt was made to examine the genetic variation (HELlER, 1996; Ginwal et al., 2004). The objective of the present investigation was to understand the nature, extent and pattern of variation existing in different populations of $J$. curcas in respect to seed morphology, germination and seedling growth. Such an investigation may help in early evaluation of criteria for selection of some prominent traits both in the laboratory and nursery conditions, which may be related to subsequent performance in the field.

\section{Material and Methods}

Seeds were collected from ten sources spread in the state of Madhya Pardesh and adjoining regions of Maharashtra in central India, with considerable geographic isolation. The area sampled ranged from $73.23^{\circ}$ to $81.4^{\circ} \mathrm{E}$ longitude and $19.35^{\circ}$ to $23.2^{\circ} \mathrm{N}$ latitude (Table 1 ). From each of the sources, seeds were collected from ten average marked trees, located about $100 \mathrm{~m}$ apart from each other in order to avoid narrowing down of the genetic base due to relatedness or inbreeding (TURNBULL, 1975). The variation in seed and seedling characteristics was investigated as under:

\section{Seed morphology}

From each seed lot of the ten sources, colour of fresh seeds was determined by matching them with the standard colour chart published by the Royal Horticulture Society (1966). Further seeds were drawn randomly and measured for their maximum length, width and thickness in millimetre up to two decimal places using an electronic vernier calliper. For measurement of seed weight 8 replicates with 100 seeds each were used and expressed as weight of whole seed, seed coat and kernel.

\section{Seed germination and seedling growth traits}

Seeds were air-dried properly and fumigated with Nuvan, thereafter treated with $0.1 \%$ Captan before storing in container at ambient room temperature. Germination trials were conducted both in laboratory and nursery condition, after giving a uniform treatment of $24 \mathrm{~h}$ pre-soaking of seeds in normal water. In laboratory condition, seeds were germinated at an alternative tem- perature of $30 / 20^{\circ} \mathrm{C}$ with $8 / 16 \mathrm{~h}$ illumination on moist white quartz sand using four replicates of 100 seeds each. Test was terminated on $28^{\text {th }}$ day when no further germination was observed. In nursery, four replicates of 100 seeds each were sown in poly bags around mid February at Tropical Forest Research Institute, Jabalpur, India.

The potting media consisted of soil : sand : FYM mixed in the ratio of $1: 1: 1$ (volume basis), treated with aldrex to avoid any chance of insect attack. Irrigation and weeding was carried out regularly and when required. In both the cases, seeds were considered germinated when the radicle had emerged about $1-\mathrm{cm}$ above the surface of sowing media. Seed germination was recorded and quantified as viability percentage, germination percentage, germination energy, and germination value (Czabator, 1962). Seedling traits in nursery were recorded for plant survival percentage (after 1 and 6 months), seedling height (in $\mathrm{cm}$ ), collar diameter (in $\mathrm{mm}$ ), number of leaves per plant, above and below ground biomass and total biomass (g/seedling). For each parameter 25 plants per seed source were selected.

\section{Statistical analysis}

Data were subjected to analysis of variance and covariance. The variance component: $V_{p}$ (phenotypic variance), $\mathrm{V}_{\mathrm{g}}$ (genotypic variance), $\mathrm{V}_{\mathrm{e}}$ (environment variance) were calculated according to GUPTA (1994). Coefficient of variation, PCV (phenotypic coefficient of variation), GCV (genotypic coefficient of variation), ECV (environment coefficient of variation), broad sense heritability, estimated genetic advance and genetic gain were determined as suggested by JoHnson et al. (1955 a,b).

\section{Results \\ Seed morphology}

Seed sources of $J$. curcas revealed slight difference in seed colour pattern of their seed-coat (Table 1). Seeds collected from Gondia and Balaghat matched to the black group (202A) colour pattern, while remaining matched to three brown groups, i.e. $200 \mathrm{~A}, \mathrm{~B}, \mathrm{C}$. Weight of the whole seeds and its components revealed maximum weight in Chhindwara source while it was significantly low for Balaghat and Jabalpur sources. The coefficient of variance (CV) for weight of whole seeds, seed-coat and kernal were recorded 10.25, 6.15 and $13.18 \%$ respectively (Table 2 ). Seed size, i.e. length, width and thickness has also shown a similar trend. Maximum seed size was recorded for Chhindwara

Table 1. - Geographic information of the seed sources of J. curcas and their seed-coat color pattern.

\begin{tabular}{llllllll}
\hline S.No. & Seed source & $\begin{array}{l}\text { Latitude } \\
\left(\mathbf{0}^{\mathbf{N}}\right)\end{array}$ & $\begin{array}{l}\text { Longitude } \\
\mathbf{0}^{\mathbf{0}} \mathbf{E}\end{array}$ & $\begin{array}{l}\text { Altitude } \\
(\mathbf{m a s})\end{array}$ & $\begin{array}{l}\text { Rainfall } \\
(\mathbf{m m})\end{array}$ & $\begin{array}{l}\text { Mean Temp. } \\
\mathbf{0} \mathbf{C}(\mathbf{m i n}-\mathbf{m a x})\end{array}$ & Seed Colour \\
\hline 1 & Gondia (MP) & 20.38 & 79.50 & 550 & 1200 & $13.4-42.6$ & Black Group (202 A) \\
2 & Bichhia (MP) & 22.26 & 80.42 & 450 & 1490 & $8.7-43.0$ & Brown Group (200 C) \\
3 & Balaghat (MP) & 23.20 & 79.57 & 70 & 1253 & $10.8-43.5$ & Black Group (202 A) \\
4 & Niwas (MP) & 21.32 & 81.4 & 450 & 1365 & $8.2-43.2$ & Brown Group (200 C) \\
5 & Khandwa (MP) & 22.10 & 75.56 & 500 & 1272 & $11.5-42.9$ & Brown Group (200 A) \\
6 & Burhanpur (MP) & 21.20 & 76.11 & 250 & 1272 & $11.5-42.9$ & Brown Group (200 A) \\
7 & Nasik (Mahrashtra) & 19.35 & 73.23 & 513 & 714 & $8.7-36.4$ & Brown Group (200 B) \\
8 & Chhindwara (MP) & 21.27 & 78.15 & 900 & 1063 & $4.2-41.6$ & Brown Group (200 A) \\
9 & Kundam (MP) & 23.12 & 80.21 & 380 & 1253 & $10.8-43.5$ & Brown Group (200 B) \\
10 & Jabalpur (MP) & 22.49 & 79.22 & 393 & 1263 & $11.0-43.5$ & Brown Group (200 C) \\
\hline
\end{tabular}


Table 2. - Variability estimates in J. curcas for seed and seedling traits in laboratory and nursery conditions.

\begin{tabular}{llllll}
\hline S.No. & Parameters & Range & Mean & CD & CV \% \\
\hline 1 & Weight of 100 whole seeds (g) & $2.95-3.91$ & 3.49 & 0.237 & 10.25 \\
2 & Weight of 100 seedcoat (g) & $1.14-1.38$ & 1.29 & 0.092 & 6.15 \\
3 & Weight of 100 kernel & $1.79-2.54$ & 2.20 & 0.251 & 13.18 \\
4 & Seed length (mm) & $17.47-18.64$ & 18.12 & 0.502 & 2.00 \\
5 & Seed width (mm) & $10.83-11.35$ & 11.06 & 0.235 & 1.31 \\
6 & Seed thickness (mm) & $8.47-9.14$ & 8.92 & 0.376 & 2.18 \\
7 & Seed viability \% (Lab) & $75.25-91.25$ & 84.58 & 3.05 & 6.57 \\
8 & Seed germination \% (Lab) & $61.25-85.75$ & 74.48 & 2.01 & 10.03 \\
9 & Germination energy \% (Lab) & $46.75-75.0$ & 60.95 & 1.30 & 11.27 \\
10 & GV (Lab) & $25.59-57.4$ & 41.25 & 2.89 & 27.41 \\
11 & Seed germination \% (Nry) & $57.5-78.75$ & 68.13 & 1.43 & 9.26 \\
12 & Germination energy \% (Nry) & $40.25-60.25$ & 50.5 & 1.48 & 9.92 \\
13 & GV (Nry) & $14.46-29.67$ & 21.87 & 1.30 & 27.12 \\
14 & Seedling survival \% after 1 month & $97.09-99.36$ & 98.22 & 1.16 & 0.83 \\
15 & Seedling survival \% after 6 months & $96.67-99.04$ & 97.82 & 0.90 & 0.84 \\
16 & Seedling height (cm) in 6 months & $40.94-53.33$ & 47.09 & 2.22 & 8.15 \\
17 & Collar diameter (mm) in 6 months & $13.46-18.97$ & 15.98 & 1.33 & 9.11 \\
18 & No. of leaves/plant after 6 months & $9.87-16.40$ & 13.19 & 2.13 & 12.61 \\
19 & Above ground biomass (g/seedling) in 6 months & $7.96-10.68$ & 9.192 & 0.57 & 9.74 \\
20 & Below ground biomass (g/seedling) in 6 months & $1.99-2.64$ & 2.27 & 0.20 & 9.02 \\
21 & Total biomass (g/seedling) in 6 months & $9.95-13.43$ & 11.48 & 0.65 & 9.70 \\
\hline
\end{tabular}

source while minimum for Gondia. The CV for these traits was found $2.00,1.31$ and $2.18 \%$, respectively.

\section{Seed germination and seedling growth traits}

Variation in seed viability, germination percentage, germination energy and germination value $(\mathrm{GV})$ of seeds grown in laboratory was found significant among different seed sources with $\mathrm{CV}$ of $6.57,10.03,11.27$ and $27.41 \%$, respectively. Maximum values for these parameters were recorded for Chhindwara seed source while minimum for Gondia sources. Almost a similar trend was noticed in nursery germination percentage, germination energy and GV with CV of 9.26, 9.92 and $21.12 \%$, respectively. The survival percentage of seedlings after one and six months of seed sowing in nursery revealed a maximum of about $99 \%$ survival in Chhindwara source which was at par with Niwas, Bichhia, Kundam and Nasik. The CV was recorded very low, viz. 0.83 and $0.84 \%$, respectively at both the age interval (Table 2). Growth parameters were determined through measurement of seedling height, collar diameter, leaves/plant, above and below ground biomass, and total biomass after six months of sowing under nursery condition. Height growth varied significantly, cross the sources, maximum seedling height $(53.33 \mathrm{~cm})$ was recorded in
Chhindwara source while minimum $(40.94 \mathrm{~cm})$ in Gondia source. The coefficient of variation (CV) between the sources for this trait was $8.15 \%$. The collar diameter, leaves/plant, above and below ground biomass, and total biomass has also revealed a more or less similar pattern. The CV for those parameters was recorded 9.11, 12.61, 9.74, 9.02 and $9.70 \%$, respectively (Table 2).

\section{Genetic analysis}

Wide differences have been recorded for variance components of seed germination and seedling growth parameters of J. curcas seeds (Table 3). The highest phenotypic variance was found for the laboratory germination value (173.08) while the least for below ground biomass (0.044). The genetic variance varied from 0.044 to 169.11 for the same parameters. For the environment variance the maximum value was recorded for seed viability percentage in laboratory conditions (6.61) while minimum for below ground biomass (0.019). The seed vigour, i.e. germination value in nursery and laboratory conditions exhibited the highest value of PCV (31.494) and GCV (31.52), respectively, while ECV recorded maximum (9.20) for below ground biomass (Table 3). The phenotypic and genotypic variance and their coefficient of variability for most of the parameters of seed germination

Table 3. - Variances, coefficient of variability and estimate of genetic component in J. curcas for seed and seedling traits observed in laboratory and nursery conditions.

\begin{tabular}{|c|c|c|c|c|c|c|c|c|c|c|}
\hline \multirow[t]{2}{*}{$\begin{array}{l}\text { S. } \\
\text { No. }\end{array}$} & \multirow[t]{2}{*}{ Parameters } & \multicolumn{3}{|c|}{ Variances } & \multicolumn{3}{|c|}{$\begin{array}{c}\text { Co-efficient of } \\
\text { variability }\end{array}$} & \multicolumn{3}{|c|}{ Genetic component } \\
\hline & & $\mathbf{V p}$ & $\mathbf{V g}$ & Ve & PCV & GCV & ECV & \begin{tabular}{|l|}
$\begin{array}{l}\text { Herita- } \\
\text { bility }\end{array}$ \\
\end{tabular} & $\begin{array}{l}\text { Genetic } \\
\text { advance }\end{array}$ & $\begin{array}{l}\text { Genetic } \\
\text { gain }\end{array}$ \\
\hline 1 & Seed viability \% (Lab) & 45.19 & 38.58 & 6.61 & 7.93 & 7.33 & 3.03 & 85.371 & 11.821 & 10.065 \\
\hline 2 & Seed germination $\%(\mathrm{Lab})$ & 111.38 & 107.44 & 3.94 & 14.17 & 13.92 & 2.67 & 96.460 & 20.971 & 28.160 \\
\hline 3 & Germination energy $\%(\mathrm{Lab})$ & 128.73 & 126.49 & 2.24 & 18.62 & 18.45 & 2.45 & 98.260 & 22.966 & 37.680 \\
\hline 4 & $\mathrm{GV}(\mathrm{Lab})$ & 173.08 & 169.11 & 3.98 & 31.39 & 31.52 & 4.83 & 97.703 & 26.479 & 64.190 \\
\hline 5 & Seed germination $\%$ (Nry) & 94.38 & 91.898 & 2.484 & 14.260 & 14.07 & 2.314 & 97.368 & 19.486 & 28.605 \\
\hline 6 & Germination energy \% (Nry) & 83.17 & 80.058 & 3.107 & 18.059 & 17.72 & 3.491 & 96.264 & 18.084 & 35.810 \\
\hline 7 & GV (Nry) & 47.44 & 46.65 & 0.797 & 31.494 & 31.23 & 4.080 & 98.320 & 13.951 & 63.788 \\
\hline 8 & Seedling survival \% after 1 month & 1.315 & 0.677 & 0.638 & 0.838 & 0.838 & 0.814 & 51.468 & 1.216 & 1.238 \\
\hline 9 & Seedling survival $\%$ after 6 months & 1.161 & 0.775 & 0.386 & 1.101 & 0.899 & 0.635 & 66.770 & 1.448 & 1.516 \\
\hline 10 & Seedling height $(\mathrm{cm})$ in 6 months & 21.21 & 18.855 & 2.346 & 9.780 & 9.221 & 3.253 & 88.897 & 8.434 & 17.910 \\
\hline 11 & Collar diameter $(\mathrm{mm})$ in 6 months & 3.385 & 2.544 & 0.840 & 11.510 & 9.998 & 5.737 & 75.168 & 2.849 & 17.827 \\
\hline 12 & Above ground biomass ( $\mathrm{g} / \mathrm{seedling}$ ) in 6 months & 1.173 & 1.017 & 0.156 & 11.785 & 10.972 & 4.303 & 86.668 & 1.934 & 21.040 \\
\hline 13 & Below ground biomass $(\mathrm{g} / \mathrm{seedling})$ in 6 months & 0.044 & 0.044 & 0.019 & 9.216 & 9.200 & 9.200 & 99.662 & 0.432 & 18.920 \\
\hline 14 & Total biomass ( $\mathrm{g} /$ seedling) in 6 months & 1.787 & 1.585 & 0.201 & 11.643 & 10.960 & 3.900 & 88.720 & 2.440 & 21.250 \\
\hline
\end{tabular}


and seedling traits were found to be higher than corresponding environmental variance and environmental coefficient of variability (ECV). Heritability values were recorded over $75 \%$ for majority of the traits except for survival percentage. The genetic advance ranged from 26.479 ( $\mathrm{GV}$ in lab) to 0.432 (below ground biomass) while genetic gains were recorded maximum of 64.19 for $\mathrm{GV}$ in lab and minimum of 1.238 for survival percentage after 1 month (Table 3).

\section{Discussion}

The seed sources of J. curcas exhibited considerable amount of variation in morphological traits of the seeds. Analysis of variance of the data on seed weight and seed size showed that the difference between seed sources were significant $(p<0.05)$. The co-efficient of variation observed was very low with regard to seed size $(<2.2)$ while moderate for seed weight (10.25-13.18). Chhindwara seed source showed an excellent and stable performance in respect of almost all traits of seed morphology, seed germination and seedling growth. As reported elsewhere, this seed source was found to have maximum yield potential of Jatropha oil (GINWAL et al., 2004). The location of Chhindwara source is at fairly high altitude in comparison to others and is characterized with less rainfall, moderately high temperature and better soil depth as compared to the other sources (GINWAL et al., 2004). Perhaps this might have lead to a better growth of seedlings and improvement in seed characters. Variation in J. curcas seed sources with respect to their morphological characters of seed and seedlings could be due to the fact that this species grows over a wide range of climatic conditions. Populations must have experienced marked differences in selective pressure. Since the seeds were collected from different locations, from trees approximately of the same age, therefore, differences observed in seed parameters may be attributed to genetic in nature as a result of adaptation to diverse environmental condition prevailing throughout their distributional range (MATHUR et al., 1984). Apart from age, vigour, crown exposure and genotype of mother tree, soil and climate of the place of seed origin are important factors affecting the seed traits (SALAZAR and QUESADA, 1987).

The variance registered in $J$. curcas for seed germination, seedling growth and biomass parameters showed considerable variation. The small value of error or environmental variances of the seedling growth traits suggests that majority of characters are under genetic control. All the variability estimates for seed behaviour have expressed high genotypic variability and heritability. The genotypic coefficients of variability and heritability were recorded to be high for viability of seed, germination percentage, germination energy and GV. Heritability in broad sense may give useful indication about the relative value of selection of the material at hand (GINWAL and GERA, 2000). Except for seed viability, other parameters of seed behaviour exhibited moderate genetic gains of 28 to $64.19 \%$ under laboratory condition. It is reported that genotype has very strong influence on vigour of the seed (ScHMIDT, 2000). Similarly, under nursery condition genotypic variance was recorded very close to phenotypic variance accompanied by very high heritability. However, the pattern has been observed to be the same for genotypic co-efficient of variability. The genetic gains obtained for all parameters except survival percentage were moderately high suggesting that the additive gene effects were highly heritable. Therefore, selection based on these parameters holds good for nursery conditions on seed behaviour.

Since germination energy is a measure of speed of germination, it gives an idea of the vigour of the seed and of the seedling, which it produces (WILlaN, 1985). The interest in germination energy is based on the theory that only those seeds which germinate rapidly and vigorously under favourable conditions are likely to be capable of producing vigorous seedling in field conditions, whereas weak or delayed germination is often fatal (AlDHOUs, 1972). Result of the present study strongly supports this hypothesis as seed sources having higher seed germination also had better field performance. Germination value is a further expression of germination energy and has been used as an integrated measure of seed quality in Acacia nilotica (GINWAL and Gera, 2000), Pinus keriya (Costales, 1978), Pinus roxburghii (Roy et al., 2004) and Terminalia ivorensis (OKORO, 1976).

The differences observed for germination parameters are genetic in nature because the environmental deviations were negligible for the experimental site, while the randomization and replication must have further reduced the chances of site effects. This also explains the variation in observed phenotypic values (VAKSHASYA et al., 1992). In the present study, the seed sources are evenly distributed resulting in lack of large climatic differences within the sampling ranges. However, small and distant pockets of $J$. curcas plants scattered within different seed sources may have restricted gene flow from population to population and therefore, resulted in a discontinuous type of variation in germination characteristic, which are genetically controlled (WHITTINGTON, 1973).

The present study revealed that considerable genetic variability exists in J. curcas with respect to seed morphology, seed germination and seedling growth characteristics. On the basis of our results, eventually, it may be concluded that the Chhindwara source is superior among all seed sources. Therefore, it is advisable that this seed source should be used for collection of bulk quantity of seeds to achieve better productivity.

\section{Acknowledgements}

The main research work has been done while authors were associated with Tropical Forest Research Institute, Jabalpur (MP) India. Therefore, we are grateful to the Director, Tropical Forest Research Institute, Jabalpur, for providing necessary facilities to conduct the experiments.

\section{References}

Aldhous, J. R. (1972): Nursery practice. Forestry Commonwealth Bulletin, No. 45: 16-17, London. 
Costales, A. B. and V. P. Veracion (1978): Germination of Benguet pine seeds at various intervals of watering. Sylvatrop 3(4): 243-245.

CzABATOR, F. J. (1962): Germination Value: an index combining speed and completeness of pine germination. Forest Science 8: 386-396.

GinwaL, H. S. and M. GERA (2000): Genetic variation in seed germination and growth performance of 12 Acacia nilotica provenances in India. Journal of Tropical Forest Science 12(2): 286-297.

Ginwal, H. S., P. S. Rawat and R. L. SRIvastava (2004): Seed source variation in growth performance and oil yield of Jatropha curcas Linn. in central India. Silvae Genetica 53(4): 186-192.

GuptA, S. P. (1994): Statistical methods, XV Ed. Sultan Chand and Sons, Darya Ganj, New Delhi.

HelleR, J. (1996): Physic nut. Jatropha curcas L. Promoting the conservation and use of underutilized and neglected crops. 1. Institute of Plant genetics and Crop Plant Research, Gatersleben/IPGRI, Rome. 66pp.

Johnson, H. W., H. F. RoBinson and R. F. Comstock (1955a): Estimates of genetic and environmental variability in Soyabean. Agron. J. 47: 314-318.

Johnson, H. W., H. F. RoBinson and R. F. Comstock (1955b): Genotypic and phenotypic correlation in soybean and their implication in selection. Agron. J. 47: 477-483.

MathuR, R. S., K. K. Sharma and M. M. S. RAWAT (1984): Germination behaviour of provenances of Acacia nilotica sp. indica. Indian Forester 110: 435-449.

OKoRo, O. O. (1976): Germination of Terminalia ivqrensis seeds source under various conditions of germination.
In 'Seed problem' Proceedings second international symposium on physiology of seed germination. October 1976, IUFRO, Fiji, Japan.

Roy, S. M., R. C. Thapliyal and S. S. Phartyal (2004): Seed source variation in cone, seed and seedling characteristic across the natural distribution of Himalayan low-level pine Pinus roxburghii Sarg. Silvae Genetica 53(3): 116-123.

RoYal Horticulture Society (1966): Colour chart of Royal Horticulture Society, London. L. in Costa Rica. Commonwealth Forestry Review 66: 317-324.

SALZAR, R. and M. QUESADA (1987): Provenance variation in Guazuma ulmifolia L. in Costa rica. Commonwealth Forestry Review 66, 317-324.

SCHMIDT, L. (2000): Guide to handling of tropical and sub tropical forest seeds. Danida forest seed center, Krogerupvej-21, Denmark.

TURNBULL, J. W. (1975): Seed collection - sampling consideration and collection tech. In report of FAO/DANIDA training course of forest seed collection on handling held in Chiang Mai, Thailand, Feb/March, FAO/TF/RAS-11(DEN), FAO, Rome.

VAKSHASYA, R. K., O. P. RAJORA and M. S. RAWAT (1992): Seed and seedling traits of Dalbergia sissoo Roxb.: Seed source variation studies among ten sources in India. Forest Ecology and Management 48: 265-275.

WhitTington, W. J. (1973): Genetic regulation of germination. pp. 5-30 in Seed Ecology, edited by W. HEYDECTER, Butterworth, London,

WiLlAn, R. L. (1985): A guide to forest seed handling with particular reference to the topics. FAO Forestry paper $20 / 2$.

\title{
Optimal Clone Number for Seed Orchards with Tested Clones
}

\author{
By D. LINDGREN ${ }^{1)}$ and F. PRESCHER ${ }^{2), *}$
}

(Received 13 $3^{\text {th }}$ May 2005)

\begin{abstract}
The optimal number of clones in seed orchards is discussed. A model is constructed to maximize a goodness criterion ("benefit") for seed orchards. This criterion is a function of: 1) the number of tested genotypes available for selection and planted in seed orchard; 2) the contribution to pollination from: a) the ramet itself; b) the closest neighbors; c) the rest of the orchard and sources outside the orchard (contamination); 3) variation among genotypes for fertility; 4) frequency of selfing; 5) production of selfed genotypes; 6) gene diversity (= status number); 7) influence of contamination; 8) genetic variation

1) D. LINDGREn, Department of Forest Genetics and Plant Physiology, Swedish University of Agricultural Sciences, S-90183 Umeå, Sweden. Email: Dag.Lindgren@genfys.slu.se.

2) F. PRESCHER, Svenska Skogsplantor AB, Seed production, S-34014 Lagan, Sweden. Email: Finnvid.Prescher@ skogsplantor.se.

*) Corresponding author: Finnvid PRescher.
\end{abstract}

among candidates; 9) correlation between selection criterion (e.g. height in progeny test) and value for forestry (e.g. production in forests from the orchard); and 10) the number of clones harvested. Numeric values of the entries are discussed, and values were chosen to be relevant for scenarios with Swedish conifers (focusing on Scots pine) and for loblolly pine. Benefit was maximized considering the number of clones. The optimum was 16 clones for the Swedish scenario, while less for the loblolly pine scenario. The optimum was rather broad, thus it is not essential to deploy the exact optimum, and an approximate optimum will do. A sensitivity analyses was performed to evaluate the importance of the likely uncertainty and variation in different entries. Quantification of the benefit of gene diversity is important. Other significant considerations are the genetic variance in the goal character and the ability to predict it, as well as the impact of selfing and the variation in reproductive success between clones. Twenty clones is suggested as a thumb rule for Swedish conifers. 